\title{
Halal Europe: a Premium Halal-Tayyib Brand?
}

\author{
Marco Tieman*
}

Europe is a leading exporter of food products, cosmetics and pharmaceuticals to Muslim countries in Asia and the Middle East. Unlike Australia, New Zealand, Singapore and Thailand, halal in Europe is not as good organised as compared to its food and product safety standards. While Muslim countries are introducing new halal standards and strengthening their certification requirements, exporters in European countries are increasingly facing difficulties in complying with the new halal regulations. European governments have regarded these new regulations as barriers to their trade with Muslim countries. Does this reflect their lack of understanding of halal, or do they have a valid argument?

The halal industry is currently evolving between these four phases: (1) Muslim company (viewed as the trust between buyer and seller); (2) halal product (understood as the certification of ingredients and production by a halal certification body); (3) halal supply chain (halal requirements throughout the supply chain); and (4) halal value chain (addressed by a company). Many European and Muslim countries are currently in the second phase of this evolution, concentrating mainly on product sources (ingredients) and the production line.

In contrast, Malaysia and Indonesia are moving towards developing robust halal supply chains (Phase 3). It is an emerging requirement for food, cosmetics and pharmaceutical industries. This requirement aims to provide the above mentioned Muslim markets with halal integrity, starting from the source to the point of consumer purchase. This movement coincides with the issuance of standards related to halal supply chain management, like the Indonesian (HAS 23000:2012), Malaysian (MS 2400:2010), and international halal logistics standard (IHIAS 0100:2010). This implies that halal and its regulations are not static but highly dynamic in nature.

\section{Halal and Tayyib in Europe}

Europe has one of the toughest food/product quality and safety standards in the world, which you need to comply with when producing in or exporting to the European market. Therefore, the European Government has created a solid foundation for a halal-tayyib system. 
European countries regard halal as a purely religious matter, in which the government should play no part. The reason the government keeps a distance is, as the argument goes, the separation of church and state. Because of this tradition, the process of halal certification is left to the private sector, without any control from central or local governments. Furthermore, no central or local government has ever set any requirements for any halal certification body, let alone issued accreditation themselves. Europe has no halal standard or guidelines in place, and halal is not protected by any kind of regulation.

This liberal policy has led to a growing number of private halal certification bodies in Europe. Although some of these certification bodies have a solid certification system, including a transparent halal standard that has been augmented by a solid auditing mechanism, unfortunately many still exist without such a standard system. Such problems have affected the entire reputation of the halal certification sector in Europe, undermining a 'Halal Europe' as a possible premium halal-tayyib brand.

Halal is a credence quality product whose characteristics are impossible for customers to ascertain. They are only verifiable by experts and other professional services. Similar to organic products, fair trade, and kosher, halal status is only visible through logos on product packaging.

Europe has one of the most stringent food and nutrition labelling laws in the world, including the credence logos of organic and fair trade products. But surprisingly there is no similar law for religious logos such as halal and kosher. This has resulted in many fake halal logos on retail food products, restaurants and fast-food outlets. Moreover, it means halal certificates on export shipments to Muslim countries come without any assurance.

\section{European halal export}

In the absence of European governments controlling halal in their own market, Indonesia and Malaysia have played a pivotal role in accrediting halal certification bodies in Europe. Both countries have provided some level of differentiation between credible and non-credible halal certification bodies. Halal accrediting bodies assess halal standards, auditing and certification systems, and audit any documentation employed by certification bodies.

Muslim countries in the Middle East are using the Indonesia and Malaysia list of recognised/accredited European halal certification bodies to identify the reliable ones. However, changes on this list can happen for several reasons: a certification body does not want to pay the accreditation costs; evidence emerges of a halal non-compliance event/item; a accreditation body issues a new fatwa (religious ruling) or any new halal standard that causes non-compliance. 
Delisting a European halal certification body would cause major problems for any industry in Europe certified by that body. Their halal certificate would no longer be valid.

As Indonesia and Malaysia continue to revise their halal standards and introduce new requirements for exporting countries, European countries will continue to confront new requirements, especially with regards to their slaughtering practices and ingredients sources. EU delegations in Muslim countries and individual European country embassies have been discussing and negotiating the new halal regulations with authorities and governments, demanding full transparency. They held discussions with governments, halal authorities, relevant government agencies and organised halal tours to Europe, but with little success in return.

\section{Conclusion and Recommendation}

The governments in the EU have considered halal to be a religious matter and a barrier to trade. They have therefore maintained a reactive approach to the new import regulations from Muslim countries. This scenario has resulted in an uncontrolled halal market in Europe, which has affected exports to the Muslim world.

Europe has to understand that halal, although has a religious foundation, touches various important government regulations similar to other credence characteristic products like organic and fair trade, which Europe has already been controling.

A reactive approach towards halal is very dangerous for Europe as it is very dependent on exporting products to the Muslim world. In order to protect its halal export development, Europe should therefore shift from a reactive approach to a proactive approach. To do this, Europe has to organise its own halal system first.

The following key measures are proposed:

1. To apply the labelling law to religious logos (halal and kosher) in order to provide better protection for Muslim consumers in Europe. Once this measure is implemented, European halal products will comply with the required standards.

2. In order to provide clarity to Muslims in the EU and to countries importing European halal products, European governments must develop a European halal standard.

3. In order to improve the standard of halal certification bodies in Europe, European governments have to accredit those certification bodies.

4. In order to better support those food, cosmetics and pharmaceutical industries 
that export to Muslim markets, European governments and ministries have to be more proactive in maintaining relationships with leading halal authorities in Muslim countries.

5. European governments should support the accreditation offered by Indonesian and Malaysian halal accreditation authorities by providing an European office for these authorities.

Although the halal market is growing significantly, it has a shortage of high quality certified foods, cosmetics and pharmaceutical ingredients and final products. European industries can serve these attractive Muslim markets, but only with effective support and control from the EU. By organising halal certification in Europe, Europe could become the world's premium halal-tayyib brand. This, however, requires effective control and regulations.

* Marco Tieman is Adjunct Professor with Universiti Tun Abdul Razak (Malaysia), where he is responsible for research in halal supply chain management. He obtained his Master's degree in industrial engineering with the University of Twente (the Netherlands) in 1997 and his PhD in business management with Universiti Teknologi MARA (Malaysia) in 2013. He is also the CEO of LBB International, an international logistics consultancy and research firm specialising in halal supply chain management and halal clusters. He chaired the development of the international halal logistics standard (IHIAS, 0100:2010) under the ICCIIHI Alliance. Dr. Marco Tieman can be contacted at: marco@lbbinternational. com. 